\title{
Bacterial communities closely associated with coral tissues vary under experimental and natural reef conditions and thermal stress
}

\author{
T. D. Ainsworth*, O. Hoegh-Guldberg \\ Centre for Marine Studies and ARC Centre of Excellence for Coral Reefs Studies, University of Queensland, St. Lucia, \\ Queensland 4072, Australia
}

\begin{abstract}
The coral holobiont model highlights the integral role bacteria play in the health of reefbuilding corals. Documenting the natural diversity of bacterial communities within, and closely associated with, coral tissues provides information on the diversity, interaction and roles of bacteria to the function of reef-building corals. Fluorescence in situ hybridisation was used to visualise bacterial communities closely associated with the tissues of experimentally manipulated reef corals to determine how tissue-associated coral-bacterial interactions vary from normal associations in apparently healthy reef corals, to those occurring in controlled and thermally stressed experimental conditions. Branches of 2 coral species of the Great Barrier Reef, Acropora aspera and Stylophora pistillata, were collected from reefs adjacent to Heron Island and were maintained in controlled outdoor flowthrough aquaria conditions. Following acclimation, the branches were stressed using elevated temperatures to investigate the in situ (within-tissue) bacterial community changes. In situ bacterial community dynamics were found to vary not only due to maintenance within the aquaria conditions, but also following coral bleaching. An aggregation of rod-shaped $\gamma$-proteobacteria was evident within the gastrodermis of corals regardless of health or bleaching status, consistent with aggregations described within other coral species. However, bacterial colonisation of the tissues occurred only following the temperature-induced bleaching of the coral tissues. This study demonstrates that the natural bacterial communities of corals are severely altered during stress associated with experimental and field conditions, which suggests a potential mechanism for the link between disease and stresses arising from global warming.
\end{abstract}

KEY WORDS: Coral $\cdot$ Bacterial associations $\cdot$ Coral bleaching

Resale or republication not permitted without written consent of the publisher

\section{INTRODUCTION}

Coral diseases are now widely reported on reefs worldwide and are increasing in incidence and virulence, contributing to worldwide reef degradation (Harvell et al. 2002, Sutherland et al. 2004). The recent increase in coral disease events has been linked to environmental stress and climate change (Aronson \& Precht 2001, Harvell et al. 2002, Lesser et al. 2007). Both the increased coral host susceptibility (Lesser et al. 2007) and increased pathogenicity of microbial communities (Rosenberg \& Ben-Haim 2002, Bruno et al. 2007) have recently been proposed to be driving these incidents of disease. Given increased environmental stressors and the potential role of microbial systems in driving disease in reef ecosystems, it is necessary to investigate the causes and mechanisms that link disease and environmental stress. Therefore it is important to accurately document the role of coral microbial communities in changing reef environments. The present study examined the in situ (within-tissue) bacterial community dynamics of reef-building corals and how these change during stable and disturbed environmental conditions. 
Very little is known about in situ bacterial community dynamics within coral tissues. There is strong evidence that along with endosymbiotic dinoflagellates, bacterial communities play important roles in normal coral physiology (Rohwer et al. 2002, Lesser et al. 2004). The occurrence of highly diverse bacterial communities has been documented using culture-independent methodologies such as DNA-based phylogenetic analysis of consortia extracted from coral-symbiotic associations. While many studies have suggested key ecological and physiological roles of these complex coral-bacterial associations, only a few, such as Lesser et al. (2004), have investigated these associations specifically within the different coral layers and coral tissues. As such, little is known about the microbial processes that occur within coral tissues or how these change during stress. Koren \& Rosenberg (2006) have proposed that coral microbial diversity is high within coral tissues of the invasive Mediterranean coral Oculina patagonica, while studies using in situ techniques have revealed diverse communities associated specifically with the endolithic layer within the coral skeleton of $O$. patagonica (Ainsworth et al. 2008). The coral surface mucus layer has also been demonstrated to harbour a large diversity of coral bacterial communities (Ritchie \& Smith 1997, review by Brown \& Bythell 2005, Ritchie 2006). Lesser et al. (2004) described and demonstrated a cyanobacterial symbiont within the tissues of the Caribbean coral Montastrea cavernosa and, based on the presence of bacterial genes governing nitrogen fixation, proposed these symbionts as having a key role in coral physiology. Determining the nature of coral-bacterial associations in situ provides a basis on which to determine the physiological role of bacterial communities within reef-building corals. Determining the endosymbiotic versus the ectosymbiotic nature of different bacterial community members may also be extremely important in differentiating microbial contributions to the coral holobiont model.

We set out to explore the in situ bacterial association within the tissue layers of branching coral species and to investigate how coral-tissue bacterial associations vary in situ during controlled and thermally stressed experimental conditions. Understanding the normal, stable, and disturbed bacterial association with coral tissues provides a basis upon which to understand not only the role of bacterial associations but also their variability in stable and disturbed conditions.

\section{MATERIALS AND METHODS}

Coral sample collection. Coral were collected on SCUBA and snorkel from the reef flat (1 $\mathrm{m}$ depth, Acropora aspera) and reef slope (up to $8 \mathrm{~m}$ depth, Stylo- phora pistillata) areas of Heron Island, the southern Great Barrier Reef $\left(23.44^{\circ} \mathrm{S}, 151.91^{\circ} \mathrm{E}\right)$ during early December 2005. Coral branches were collected, held in seawater and transported immediately. Healthy coral branches of $<5 \mathrm{~cm}$ in length of $A$. aspera $(\mathrm{n}=108)$ and $S$. pistillata $(\mathrm{n}=108)$ were transported immediately to flow-through outdoor aquaria for experimental manipulation. Replicate samples of each species were also collected from each species and transported for immediate fixation $(\mathrm{n}=3)$.

Experimental design. The coral branches were randomly assigned to 1 of 4 experimental $60 \mathrm{l}$ plastic outdoor aquaria with flow rates $\sim 10 \mathrm{l} \mathrm{min}^{-1}$, and stored in polypropylene racks $<10 \mathrm{~cm}$ above the base of the tank. Two of the 4 aquaria were used as heat treatment tanks, and 2 as control tanks, which were fed from separate $1000 \mathrm{l}$ sumps. All aquaria were exposed to the natural light conditions. The tanks were maintained for $4 \mathrm{~d}$ prior to coral collection to allow the system to stabilise. After collection of the coral colonies the system was left at ambient flow through conditions for $5 \mathrm{~d}$ to acclimate before the start of the experiment. The control tanks remained throughout the experiment at ambient sea surface temperatures $\left(28^{\circ} \mathrm{C}\right)$, while heat treatments involved a daily $1^{\circ} \mathrm{C}$ increase in water temperature over a $4 \mathrm{~d}$ period up to the bleaching temperature of $32^{\circ} \mathrm{C}$, where it was held for $2 \mathrm{~d}$. The treatment sump was heated and the temperature was increased in the sump starting at 08:00 $\mathrm{h}$ on each experimental day. The temperature gradually increased over a period of 4 hours, and peaked within the experimental tanks at approximately midday. Temperature in each of the 4 tanks was monitored using Odyssey data loggers (Odyssey House) every 2 min throughout the experimental and acclimation periods. Two entire branches were randomly sampled from each tank each day from $1 \mathrm{~d}$ before the experimental period and daily throughout the experimental period.

Fixation and processing of coral samples. Coral samples from experimental conditions $\left(2\right.$ aquarium $^{-1}$ $\mathrm{d}^{-1}$ for a total of $5 \mathrm{~d}$ ) were collected and fixed individually in $50 \mathrm{ml}$ of $4 \%$ (w/v) paraformaldehyde in sterile phosphate-buffered saline (PBS, $\mathrm{pH} 7.4$ ) for $12 \mathrm{~h}$ at $4^{\circ} \mathrm{C}$ (Ainsworth et al. 2006, 2007a). Following fixation, samples were stored in PBS at $4{ }^{\circ} \mathrm{C}$, and subsequently decalcified with $20 \%(\mathrm{w} / \mathrm{v})$ EDTA (pH 8). Decalcified coral samples were then processed for standard paraffin embedding with washes of $70 \%, 80 \%, 2$ of $95 \%$ and 3 of $100 \%$ ethanol for 40 min each, 3 xylene washes for $40 \mathrm{~min}$ and then 3 paraffin washes under vacuum for 40 min each prior to embedding in paraffin. Serial cross sections $(4 \mu \mathrm{m})$ were taken from the replicate coral samples collected from each aquarium on each day of the experimental period and prior to experimental manipulation, and were collected onto $\mathrm{Su}-$ 
perfrost Plus slides (Menzel). The tissue sections were then stained using Harris's haematoxylin and eosin (with phyloxine B) (Sigma-Aldrich, HHS32 and HT110-1-32) and adjacent sections were used in fluorescence in situ hybridisation (FISH).

FISH. Visualisation of bacterial communities associated with coral tissues was conducted using FISH combined with spectral imaging (Ainsworth et al. 2006). Serial $(4 \mu \mathrm{m})$ sections of each sample collected were used in the hybridisation with bacterial probes to determine the presence of bacteria within the tissues and determine if the bacteria were members of the $\gamma$-proteobacterial group and Vibrio genus. The probes used included: universal bacterial probe mix (EUBmix), a $\gamma$-proteobacteria probe mix (GAM42A) and a Vibrio sp. (MV) (see Amann et al. 1990, 1995, 1996, 2000, Manz et al. 1992, 2000, Daims et al. 1999, Moreno et al. 1999, Moter \& Gobel 2000). The probes, Cy3-labelled oligonucleotide probes (Thermo Electron), were used in a standardised FISH protocol (Manz et al. 2000). The hybridisation was conducted using $35 \%$ formamide in hybridisation buffer $(0.9 \mathrm{M}$ $\mathrm{NaCl}, 0.01 \%$ sodium dodecyl sulphate [SDS], $0.01 \mathrm{M}$ Tris- $\mathrm{HCl} \mathrm{pH} \mathrm{7.2)} \mathrm{for} 1.5 \mathrm{~h}$ at $46^{\circ} \mathrm{C}$, followed by a $10 \mathrm{~min}$ wash in pre-warmed wash buffer $(0.08 \mathrm{M} \mathrm{NaCl}, 0.01 \%$ SDS, 0.01 M Tris-HCl pH 7.2, 0.05 M EDTA). A Zeiss Meta 510 confocal scanning laser microscope combined with spectral emissions profiling of tissue autofluorescence was used for visualisation of FISHlabelled bacterial communities in association with coral tissues and the disease lesion.

Transmission electron microscopy. Samples of Acropora aspera $(\mathrm{n}=3)$ and Stylophora pistillata $(\mathrm{n}=3)$ from apparently healthy coral from reef conditions were also preserved for transmission electron microscopy for investigation of in situ bacterial communities and bacterial morphology. Small fragments $(0.2$ to $0.5 \mathrm{~cm}^{3}$ ) from each colony were immediately fixed in $3 \%$ glutaraldehyde in 0.1 M cacodylate buffer. Sample preparation used methods outlined in Le Tissier (1990), and decalcified in $20 \%$ EDTA over 2 wk at $4{ }^{\circ} \mathrm{C}$. Sample grids with ultra-thin sections were viewed in a transmission electron microscope (JEOL 1010) at acceleration voltage $80 \mathrm{kV}$, and images taken using the Megaview III Soft Imaging system.

\section{RESULTS}

\section{In situ bacterial populations associated with natural coral communities}

The natural bacterial community associations within the tissues of reef-building corals were limited to bacterial aggregates within the gastrodermis. Both Acro- pora aspera and Stylophora pistillata were found to have pleiomorphic bacterial aggregates within the gastrodermis (Fig. 1). This is consistent with previous reports (Peters et al. 1983, Peters 1984, Santavy \& Peters 1997, Rohwer et al. 2002, Ainsworth et al. $2007 a, b)$ of similar bacterial communities associated with the gastrodermis tissue layer of both healthy and diseased coral tissues (Table 1). Electron microscopy of tissues of both $A$. aspera and $S$. pistillata of the Great Barrier Reef show apparently uniform rod-shaped morphology of the 1 to $3 \mu \mathrm{m}$ bacteria within the aggregates, and this appears as the only morpho-type identified within the aggregate regardless of aggregate size (Fig. 1). Using FISH, these bacterial aggregates were identified as members of the $\gamma$-proteobacteria group by selective binding of the GAM42A and EUBmix probes (Fig. 1). A lack of binding with a Vibrio sp.specific group probe (MV) suggests that these bacteria are not members of the Vibrio genus. Aggregate size was found to vary from as little as $7 \mu \mathrm{m}$ to $>80 \mu \mathrm{m}$ in diameter (Fig. 2). Based upon estimations of the aggregate volume (volume of ellipsoid $=1 / 6 \pi \times$ length $\times$ width $\times$ depth), the bacterial density within a $5 \mu \mathrm{m}$ thick section of an aggregate ranged from $\sim 120$ bacteria within a single aggregate measuring $7 \mu \mathrm{m}$ long by $5 \mu \mathrm{m}$ wide, up to 2700 bacteria within a single aggregate measuring $80 \mu \mathrm{m}$ long by $10 \mu \mathrm{m}$ wide.

\section{Bacterial community changes associated with experimental conditions}

Bacteria within the coral tissue layers in controlled and experimentally heated aquarium conditions were both found to be different to those associated with apparently healthy, naturally occurring, coral tissuebacterial community associations. Bacterial populations penetrated and proliferated within the outer tissue layers (epithelium) in what appear to be mucus cells, and penetrated throughout the adjacent coral cells and tissue regions (Fig. 3A-C). These bacterial interactions within the coral epithelium tissue layer were apparent in both the control and the thermally stressed conditions (Fig. 3A-F), and occurred within $3 \mathrm{~d}$ of being held in aquaria and experimental conditions (Table 2). These interactions were not found in apparently healthy, normal coral populations sampled directly from the reef without maintenance within the aquaria or experimental conditions. While this proliferation did change the 'normal' flora seen within the tissues of coral it did not appear to have any obvious short-term health consequences to the corals maintained in thermal experimental and control conditions. A complete bacterial colonisation or overgrowth of the coral tissues was only evident after increasing thermal 

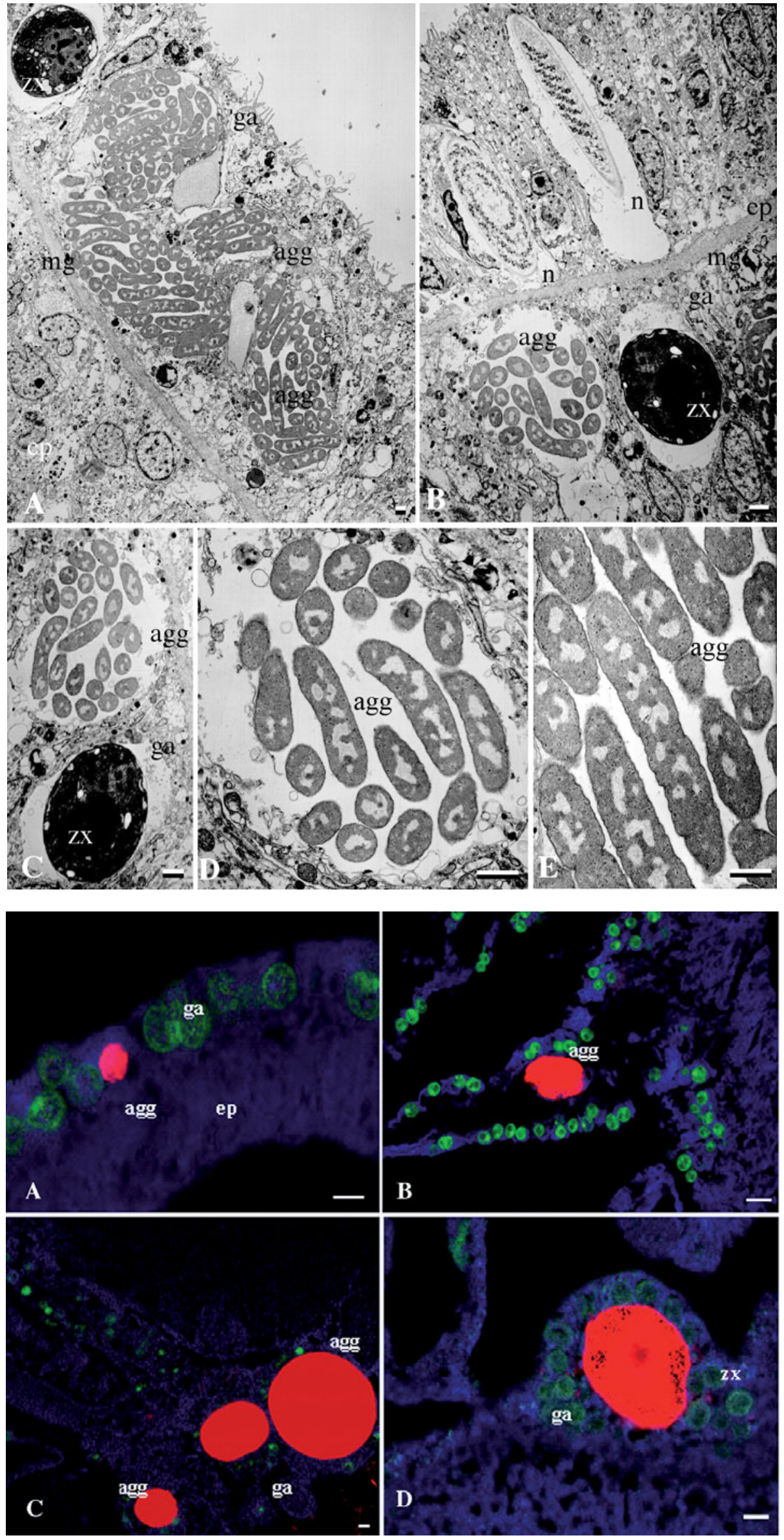

Fig. 1. Electron micrographs of rod-shaped bacteria within the gastrodermis of Acropora aspera indicate the consistent morphology of the populations in large aggregates of (A) $\sim 60 \mu \mathrm{m}$ and (B) $\sim 25 \mu \mathrm{m}$ (diameter). (C-E) Aggregates at greater magnification. agg: aggregate; ep: epithelium; ga: gastrodermis; mg: mesoglea; n: nematocyst; zx: endosymbiotic dinoflagellate. Scale bars (bottom right of panels) $=1 \mu \mathrm{m}$
Fig. 2. (A-D) Size variability of bacterial aggregates within coral gastrodermal tissue layers from as small as $7 \mu \mathrm{m}$ (A) to $80 \mu \mathrm{m}$ (D) in length in Acropora aspera as identified using EUBmix, similar to that of Tabular Acropora of the GBR (C). Location and morphology is consistent with branching Acroporid coral of the Red Sea (D). Blue: coral tissue; green: endosymbiotic dinoflagellates; red: bacteria; agg: aggregate; ep: epithelium; ga: gastrodermis; zx: endosymbiotic dinoflagellates. Scale bars $=10 \mu \mathrm{m}$ 
Table 1. In situ bacterial aggregates in reef-building corals, including healthy, thermally stressed (T-S), white syndrome (WS) and white disease (WD) affected corals. GBR, Great Barrier Reef

\begin{tabular}{|c|c|c|c|c|c|}
\hline $\begin{array}{l}\text { Genus or } \\
\text { species }\end{array}$ & Location & $\begin{array}{l}\text { Health } \\
\text { status }\end{array}$ & \multicolumn{2}{|c|}{$\gamma$-proteobacteria aggregates } & Source \\
\hline \multirow[t]{4}{*}{ Acropora aspera } & GBR & Healthy & Present & Not present & Ainsworth et al. (2006) \\
\hline & GBR & $\mathrm{T}-\mathrm{S}$ & Present & & Present study \\
\hline & GBR & Bleached & Present & Present & Present study \\
\hline & GBR & Control aquaria & Present & Present & Present study \\
\hline \multirow[t]{4}{*}{ Acropora sp. } & GBR & WS & Present & & Ainsworth et al. (2007a) \\
\hline & Eilat & Healthy & Present & Not present & Ainsworth et al. (2007b) \\
\hline & Eilat & WS & Present & Not present & Ainsworth et al. (2007b) \\
\hline & Caribbean & WD & Present & & Peters (1984) \\
\hline \multirow[t]{6}{*}{ Stylophora pistilata } & GBR & Healthy & Present & Not present & Present study \\
\hline & GBR & $\mathrm{T}-\mathrm{S}$ & Present & Not present & Present study \\
\hline & GBR & Bleached & Present & & Present study \\
\hline & GBR & Aquaria & Present & Present & Present study \\
\hline & Eilat & Healthy & Present & Not present & Ainsworth et al. (2007b) \\
\hline & Eilat & WD & Present & Not present & Ainsworth et al. (2007b) \\
\hline Porities sp. & Caribbean & & Present & & Rohwer et al. (2002) \\
\hline
\end{tabular}

Table 2. Acropora aspera. Identification of bacterial aggregates in the tissues of thermally stressed and control condition corals (the bleaching threshold for A. aspera on the reef flat was $32^{\circ} \mathrm{C}$ ). Ep: epithelium; Ga: gastrodermis. Bold: change in bacterial communities detected compared to that of prior samples. All corals were held for $5 \mathrm{~d}$ acclimation prior to the onset of the experiment period

\begin{tabular}{|lcccc|}
\hline $\begin{array}{l}\text { Temperature in } \\
\text { heated aquaria }\left({ }^{\circ} \mathrm{C}\right)\end{array}$ & $\begin{array}{c}\text { Tissue } \\
\text { association }\end{array}$ & $\begin{array}{c}\text { Temperature in } \\
\text { control aquaria }\left({ }^{\circ} \mathrm{C}\right)\end{array}$ & $\begin{array}{c}\text { No. of days in } \\
\text { control aquaria }\end{array}$ & $\begin{array}{c}\text { Tissue } \\
\text { association }\end{array}$ \\
\hline 28 & $\mathrm{Ga}$ & 28 & 6 & $\mathrm{Ga}$ \\
$\mathbf{3 0}$ & $\mathrm{Ga} / \mathrm{Ep}$ & $\mathbf{2 8}$ & $\mathbf{7}$ & $\mathrm{Ga} / \mathrm{Ep}$ \\
31 & $\mathrm{Ga} / \mathrm{Ep}$ & 28 & 8 & $\mathrm{Ga} / \mathrm{Ep}$ \\
32 & $\mathrm{Ga} / \mathrm{Ep}$ & 28 & 9 & $\mathrm{Ga} / \mathrm{Ep}$ \\
32 & $\mathrm{Ga} / \mathrm{Ep}$ & 28 & 10 & $\mathrm{Ga} / \mathrm{Ep}$ \\
Bleached & Colonisation & Unbleached & 11 & No colonisation \\
\hline
\end{tabular}

stress resulted in coral bleaching (after exposure to the bleaching threshold of $32^{\circ} \mathrm{C}$, and loss of the endosymbiotic dinoflagellates) (Fig. 4). Within the bleached coral tissue regions (as determined by loss of the associated endosymbiotic algae), mixed bacterial populations were detected associated within the mesentarial filaments, gastrodermis and epithelial layers. The same extent of proliferation of bacteria around the internal/mesentarial layers did not occur in any other coral tissues nor in corals maintained in control aquaria (Table 2).

\section{DISCUSSION}

Symbioses between corals and bacteria have been widely proposed in recent coral literature. Complex and diverse coral-bacterial associations have also been suggested to show species-, temporal- and spatial-specificity (Ritchie \& Smith 1997, Rohwer et al. 2002). These coral-bacterial associations are proposed to occur in several regions, including within the coral tissue layers, endolithic layer of the skeleton, and also coral surface mucus layers (Ritchie \& Smith 1997, review by Brown \& Bythell 2005, Ritchie 2006, Ainsworth et al. 2006). Determining the specific in situ bacterial associations that occur within the coral tissue layers, as opposed to within the coral surface mucus-layer, coral gut, and skeletal endolithic layers, is important in order to understand the various roles bacterial populations may play in coral physiology. In the present study, we have described the structure and dynamics of coral tissue-specific bacterial associates under normal and stressed conditions. One of the important issues to arise here is that extreme care must be taken when interpreting bacterial population changes in corals maintained in aquarium conditions. This echoes the observations of Kline et al. (2006), who found major increases in the abundance of bacteria when corals were maintained in aquaria.

The normal bacterial populations within apparently healthy coral tissues were identified as aggregates of $1 \mu \mathrm{m}$ rod-shaped $\gamma$-proteobacteria. These aggregations 

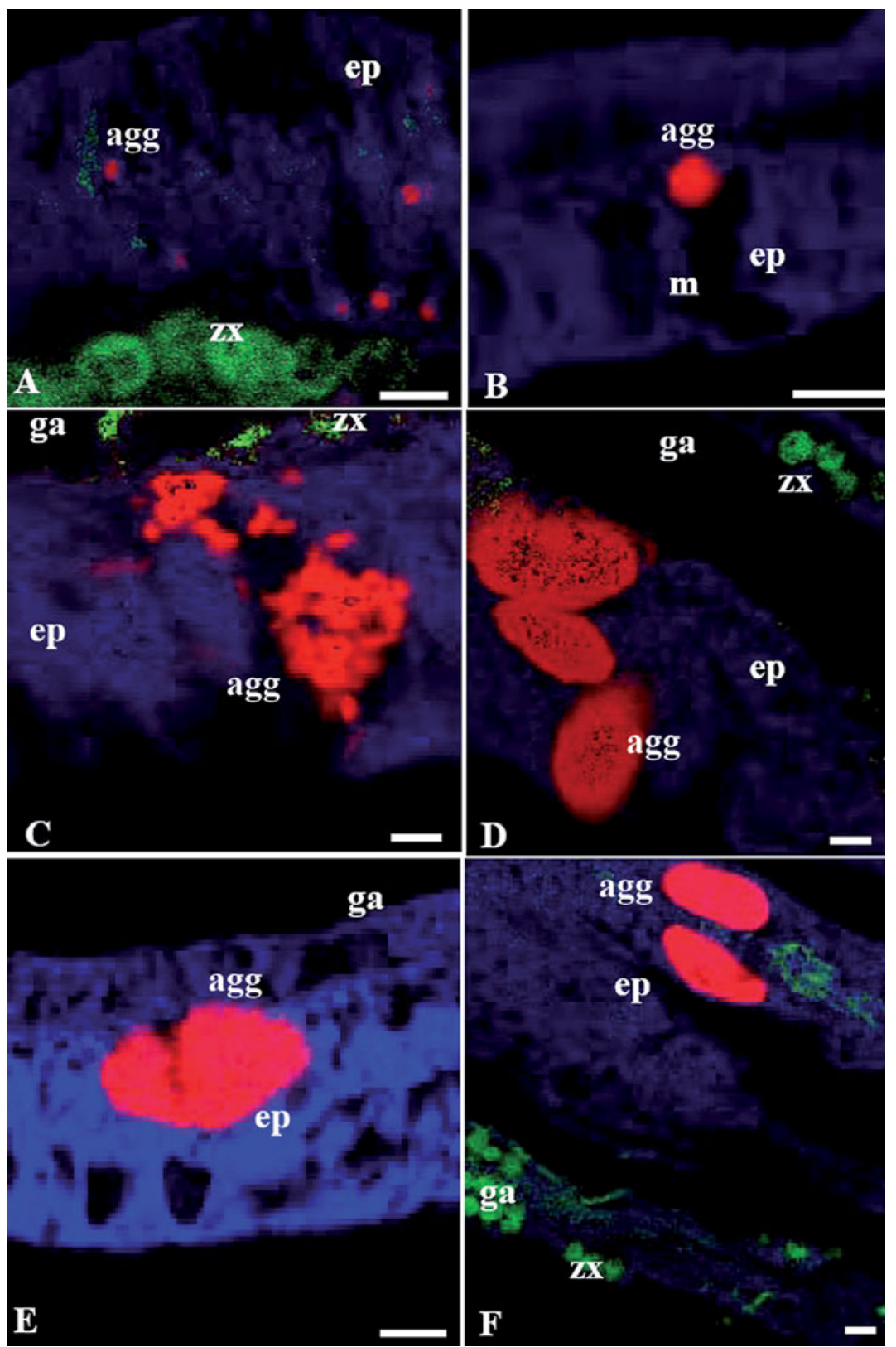
both (A-D) thermal stress, and (E,F) control conditions. Blue: coral tissue; green: endosymbiotic dinoflagellates; red: bacteria; agg: aggregate; ep: epithelium; ga: gastroderm; m: mucosal cell; zx: endosymbiotic dinoflagellates. Scale bars $=10 \mu \mathrm{m}$

were observed within vacuoles or membrane-bound regions of the gastrodermis, similar to that of the perialgal space of the coral-dinoflagellate symbiosis. The $\gamma$-proteobacteria bacterial aggregates within the gastrodermis were uniform in structure and located within the gastrodermis tissue layers, consistent with previous reports in other corals (Peters et al. 1983, Peters 1984, Santavy \& Peters 1997, Rohwer et al. 2002, Ainsworth et al. $2007 a, b)$ (Table 2). Specific coral-bacterial symbioses have previously been described and nitrogen-fixing cyanobacterial symbionts were found within the tissue layers of Montastrea cavernosa (Lesser et al. 2004). Here, our data support previous suggestions that the rod-shaped $\gamma$-proteobacterial population within the gastrodermis tissue layer may also prove to be a universal symbiont group (Peters 1984, Santavy \& Peters 1997, Rohwer et al. 2002, Ainsworth et al. 2006, 2007a,b). Previous descriptions of these include dense ovoid bacterial aggregates in corals of the Caribbean (Peters et al. 1983, Peters 1984, Santavy \& Peters 1997) and a universally dominant PA1 ribotype from poritid corals (Rohwer et al. 2002). Further investigation should be conducted to determine the identity, function and role of these widespread and potentially symbiotic bacteria.

Bacterial aggregates were found only within the gastrodermis layer of corals taken directly from the field. This, however, was not the case for corals maintained in captivity. In both controlled ambient conditions and thermally stressed conditions, the in situ bacterial association changed from the limited gastrodermis aggregates seen in corals collected from the natural reef environment, to bacterial communities penetrating and proliferating within the outer tissues of the epithelial layer. The bacterial penetration of the epithelial layer of corals maintained in control aquaria was evident throughout the experimental period (a total of $11 \mathrm{~d}$ ), during which time corals did not reveal macroscopically apparent adverse effects such as tissue loss or whitening of the tissues. These changes may be a product of several conditions, including fragmentation of the tissues, handling of the coral samples in preparation of experimental conditions, or a result of the altered and increased bacterial loads of contained aquarium conditions compared to those normally experienced by the corals in reef flat conditions (Kline et al. 2006). The coral mucus-associated microbial community has also been shown to undergo a significant shift during maintenance within aquarium conditions (Kooperman et al. 2007). It is important to determine if this shift in 

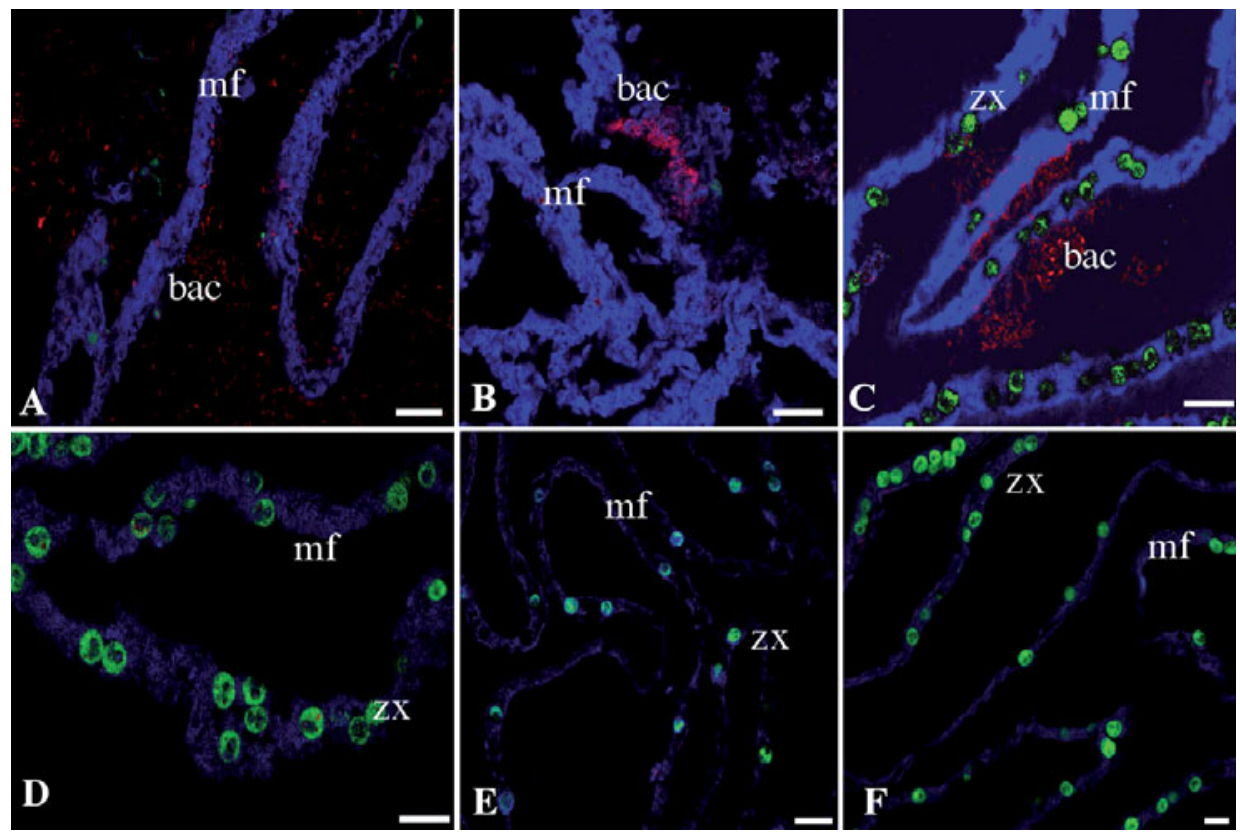

Fig. 4. Acropora aspera. Bacterial colonisation of mesentarial filaments of following thermal stress and coral bleaching in regions with $(A, B)$ no or few endosymbiotic dinoflagellates, and (C) many endosymbiotic dinoflagellates, but is not evident in control conditions (D) or prior to bleaching $(\mathrm{E}, \mathrm{F})$. bac: bacteria; $\mathrm{mf}$ : mesentarial filaments; zx: endosymbiotic dinoflagellates. Scale bars $=20 \mu \mathrm{m}$ mucus-associated communities allows bacterial communities to penetrate and proliferate within coral tissues that would not normally occur. This mucusassociated community change, combined with the results of the present study, have important ramifications for the interpretation of culture-based bacterial isolation studies when applied to corals in experimental scenarios.

\section{CONCLUSIONS}

These results highlight a series of important questions that need to be addressed relating to our understanding of the role of coral-bacterial associations, the impact of experimental stressors in changing normal associations, and the role of bacterial communities in colonisation of bleached coral tissue. In general, our understanding of in situ coralbacterial community dynamics and endo- and ectobacterial symbioses remains in its infancy. Our study provides evidence of potential bacterial endosymbionts that may play a role in the physiology and ecology of corals. The details of these interactions remain sketchy and should be the focus of future work. Symbionts that are associated with the outer layers, while not prominent in the present study, should not be ignored. It is clear overall, however, that there are significant and important features associated with the bacterial communities of corals that require description before we fully understand the linkages between stress, disease and the microbial flora of reef-building corals.
Acknowledgements. We thank Dr. S. Dove, Dr. O. Levy, and Ms. R. Middlebrook for assistance during sample collection at Heron Island Research Station. We also thank the staff of Heron Island Research Station and Mr. D. Harris and Dr. B. Leggat for assistance with the experimental set-up, design and sample collection, and Ms. D. Burgess. We thank the ARC Centre of Excellence for Coral Reef Studies (www.coralcoe.org.au/) and the Coral Reef Targeted Research Program (www.gefcoral.org) for financial support of this research project.

\section{LITERATURE CITED}

Ainsworth TD, Fine M, Blackall LL, Hoegh-Guldberg O (2006) Fluorescence in situ hybridisation and spectral imaging of coral-associated bacterial communities. Appl Environ Microbiol 72:3016-3020

Ainsworth TD, Kvennefors EC, Blackall LL, Fine M, HoeghGuldberg O (2007a) Disease and cell death in white syndrome of Acroporid corals on the Great Barrier Reef. Mar Biol 151:19-29

Ainsworth TD, Kramasky-Winter E, Loya Y, Hoegh-Guldberg O, Fine M (2007b) Coral disease diagnostics: What's between a plague and a band? Appl Environ Microbiol 73:981-992

Ainsworth TD, Roff G, Fine M, Hoegh-Guldberg O (2008) Bacteria are not the cause of mass coral bleaching. Revisiting the annual bleaching of Oculina patagonica in the Mediterranean Sea. ISME J 2:67-73

Amann RI, Binder BJ, Olson RJ, Chisholm SW, Devereux R, Stahl DA (1990) Combination of 16S rRNA-targeted oligonucleotide probes with flow cytometry for analysing mixed microbial populations. Appl Environ Microbiol 56:1919-1925

Amann RI, Ludwig W, Schleifer H (1995) Phylogenetic identification and in situ detection of individual microbial cells without cultivation. Microbiol Rev 59:143-169

Amann R, Snaidr J, Wagner M, Ludwig W, Scleifer KH (1996) In situ visualisation of high genetic diversity in a natural microbial community. J Bacteriol 178:3496-3500 
Amann R, Fuchs BM, Behrens S (2001) The identification of micro-organisms by fluorescence in situ hybridisation. Curr Opin Biotechnol 12:231-236

Aronson RB, Precht WF (2001) White-band diseases and the changing face of Caribbean coral reefs. Hydrobiologia 460:25-38

Brown BE, Bythell JC (2005) Perspectives on mucus secretion in reef corals. Mar Ecol Prog Ser 296:291-309

Bruno JF, Selig ER, Casey KS, Page CA and others (2007) Thermal stress and coral cover as drivers of coral disease outbreaks. PLoS Biol 5:e124

Daims H, Brühl A, Amann R, Schleifer KH, Wagner M (1999) The domain-specific probe EUB338 is insufficient for the detection of all bacteria: development and evaluation of a more comprehensive probe set. Syst Appl Microbiol 22: $434-444$

Harvell CD, Mitchell CE, Ward JR, Altizer S, Dobson AP, Ostfeld RS, Samuel MD (2002) Climate warming and disease risks for terrestrial and marine biota. Science 296: 2158-2162

Kline D, Kuntz NM, Breitart M, Knowlton N, Rohwer F (2006) Role of elevated organic carbon levels and microbial activity in coral mortality. Mar Ecol Prog Ser 314:119-125

Kooperman N, Ben-Dov E, Kramasky-Winter E, Braak Z, Kushmaro A (2007) Coral mucus-associated bacterial communities from natural and aquarium environments. FEMS Microbiol Lett 276:106-113

Koren O, Rosenberg E (2006) Bacteria associated with mucus and tissues of the coral Oculina patagonica in summer and winter. Appl Environ Microbiol 72:5254-5259

Le Tissier MDA (1990) The ultrastructure of the skeleton and skeletogenic tissues of the temperate coral Caryophyllia smithii. J Mar Biol Assoc UK 70:295-310

Lesser MP, Mazel CH, Gorbunov MY, Falkowski PG (2004) Discovery of symbiotic nitrogen-fixing cyanobacteria in corals. Science 305:997-1000

Lesser MP, Bythell JC, Gates RD, Johnstone RW, HoeghGuldberg O (2007) Are infectious diseases really killing corals? Alternative interpretations of the experimental and ecological data. J Exp Mar Biol Ecol 346:36-44

Editorial responsibility: Michael Kühl,

Helsingør, Denmark
Manz W, Amann R, Ludwig W, Wagner M, Schleifer KH (1992) Phylogenetic oligonucleotide probes for the major subclasses of proteobacteria: problems and solutions. Syst Appl Microbiol 15:593-600

Manz W, Arp G, Schumann-Kindel G, Szemzyke U, Reitner J (2000) Wide-field deconvolution epifluorescence microscopy combined with fluorescence in situ hybridisation reveals the spatial arrangement of bacteria in sponge tissue. J Microbiol Methods 40:125-134

Moreno Y, Arias CR, Meier H, Garay E, Aznar R (1999) In situ analysis of the bacterial communities associated to farmed eel by whole-cell hybridization. Lett Appl Microbiol 29: 160-165

> Moter A, Gobel UB (2000) Fluorescence in situ hybridisation (FISH) for direct visualisation of microorganisms. J Microbiol Methods 41:85-112

Peters EC (1984) A survey of cellular reactions to environmental stress and disease in Caribbean scleractinian corals. Helgol Meersunters 37:113-137

> Peters EC, Oprandy JJ, Yevich PP (1983) Possible causal agent of 'white band disease' in Caribbean acroporid corals. J Invertebr Pathol 41:394-396

> Ritchie KB (2006) Regulation of microbial populations by coral surface mucus and mucus-associated bacteria. Mar Ecol Prog Ser 322:1-14

Ritchie KB, Smith GW (1997) Physiological comparisons of bacterial communities from various species of scleractinian corals. Proc 8th Int Symp Coral Reef Symp, Panama 1: $512-526$

> Rohwer F, Seguritan V, Azam F, Knowlton N (2002) Diversity and distribution of coral-associated bacteria. Mar Ecol Prog Ser 243:1-10

Rosenberg E, Ben-Haim Y (2002) Microbial diseases of corals and global warming. Environ Microbiol 4:318-326

Santavy DL, Peters EC (1997) Microbial pests: coral disease in the western Atlantic. Proc 8th Int Coral Reef Symp, Panama 1:55-68

Sutherland KP, Porter JW, Torres C (2004) Disease and immunity in Caribbean and Indo-pacific zooxanthellate corals. Mar Ecol Prog Ser 266:273-302

Submitted: December 13, 2007; Accepted: September 30, 2008 Proofs received from author(s): January 15, 2009 